\title{
Pulmonary arteriovenous malformations: an uncharacterised phenotype of dyskeratosis congenita and related telomere biology disorders
}

\author{
To the Editor:
}

The telomere biology disorder (TBD) dyskeratosis congenita (DC) is a multisystem inherited bone marrow failure syndrome and cancer predisposition syndrome caused by germline mutations in telomere biology genes (DKC1, TINF2, TERC, TERT, NOP10, NHP2, CTC1, WRAP53, ACD, RTEL1 and PARN). The classic triad of reticular skin pigmentation, dysplastic nails and oral leukoplakia is diagnostic of DC $[1,2]$. Leukocyte telomere lengths less than the first percentile for age measured by flow cytometry with fluorescence in situ hybridisation are consistent with DC in the presence of other phenotypic features [3]. Pulmonary fibrosis, a known complication of DC/TBD, occurs in $\geqslant 20 \%$ of patients [1]. Pulmonary arteriovenous malformations (PAVMs) in DC have been previously described in case reports or small case series in the context of hepatopulmonary syndrome (HPS) [4-9]. Presenting features of PAVMs may overlap with those of pulmonary fibrosis, including dyspnoea, orthopnoea, platypnoea, cyanosis and digital clubbing. HPS is described as pulmonary vascular dilatation due to liver disease of any cause (cirrhotic/ noncirrhotic with/without portal hypertension), leading to deficient arterial oxygenation [10].

This multi-institutional retrospective review of medical records evaluated patients diagnosed with both DC/TBD and PAVMs. All participants were enrolled in an institutional review board-approved study at the primary reporting institution. Data were received and maintained at the National Cancer Institute (NCI; Bethesda, MD, USA) within the institutional review board-approved Inherited Bone Marrow Failure Syndromes (IBMFS) protocol (NCI02-C-0052, clinicaltrials.gov/ct2/show/NCT00027274) [11]. The study includes patients of any age, sex and race who have been diagnosed with DC/TBD based on clinical criteria and/or genetic testing positive for a known disease-causing mutation.

We report 13 unrelated patients with both DC/TBD and PAVM. Median (range) age at diagnosis of DC/TBD was 13 (1-27) years and at diagnosis of PAVMs was 15 (3-32) years. The male:female ratio was 7:6. The majority (77\%) of patients were of European ancestry. Six (46\%) patients had germline mutations in TINF2 (table 1). One patient did not have a known causative gene mutation. Data on clinical manifestations at the time of DC/TBD diagnosis were available on 12 patients and are detailed in table 1. $10(83 \%)$ patients had at least one feature of the mucocutaneous triad; all tested patients had very short telomere length for age; and six (50\%) had aplastic anaemia. 10 (77\%) out of 13 patients underwent haematopoietic cell transplant (HCT) at median (range) age $6(1-21)$ years.

The clinical details of PAVM diagnosis and management are also shown in table 1. Two (15\%) out of 13 patients had PAVMs diagnosed prior to their diagnosis of DC. Nine (90\%) out of 10 patients who underwent HCT had PAVMs diagnosed at a median (range) time interval of 5 (2-8) years after HCT. Notably, two asymptomatic patients had PAVMs diagnosed after evaluation of an unexplained decrease in diffusing capacity of the lung for carbon monoxide (DLCO). Six (46\%) patients had pulmonary fibrosis confirmed by computed tomography scan around the time of their PAVM diagnosis. DLCO was reduced (16-56\% predicted) out of proportion to other pulmonary function tests and the radiologic extent of pulmonary fibrosis, when present. Transthoracic contrast echocardiography with agitated saline bubble contrast (TTCE) was indicative of a delayed right-to-left shunt (contrast appearing in left heart $\geqslant 3$ beats

@ERSpublications

PAVMs are underrecognised in telomere biology disorders and present diagnostic and therapeutic challenges http://ow.ly/2lPc304eu0t

Cite this article as: Khincha PP, Bertuch AA, Agarwal S, et al. Pulmonary arteriovenous malformations: an uncharacterised phenotype of dyskeratosis congenita and related telomere biology disorders. Eur Respir J 2017; 49: 1601640 [https://doi.org/10.1183/13993003.01640-2016]. 


\begin{tabular}{|c|c|c|c|c|c|c|c|c|c|c|c|c|c|c|c|c|}
\hline \multirow[t]{2}{*}{ Patient } & \multicolumn{3}{|c|}{ At $\mathrm{DC} / \mathrm{TBD}$ diagnosis } & \multirow{2}{*}{$\begin{array}{l}\text { Telomere } \\
\text { length }\end{array}$} & \multirow[t]{2}{*}{ Gene, mutation } & \multirow{2}{*}{$\begin{array}{l}\text { Aplastic anaemia } \\
\text { treatment }\end{array}$} & \multirow[t]{2}{*}{ HCT indication } & \multirow{2}{*}{$\begin{array}{l}\text { Age at } \\
\text { HCT years }\end{array}$} & \multirow{2}{*}{$\begin{array}{l}\text { HCT preparation, } \\
\text { GVHD prophylaxis }\end{array}$} & \multicolumn{6}{|c|}{ At PAVM diagnosis } & \multirow{2}{*}{$\begin{array}{l}\text { Age at last } \\
\text { follow-up years }\end{array}$} \\
\hline & Age years & $\begin{array}{l}\text { Features } \\
\text { of DC triad }\end{array}$ & $\begin{array}{l}\text { Aplastic } \\
\text { anaemia }\end{array}$ & & & & & & & Age years & Presentation & Dco \% pred & $\begin{array}{l}\text { Co-existent } \\
\text { pulmonary } \\
\text { fibrosis }\end{array}$ & $\begin{array}{l}\text { Positive } \\
\text { TTCE }\end{array}$ & $\begin{array}{l}\text { Evidence of } \\
\text { liver disease }\end{array}$ & \\
\hline 1 & 13 & L & Mild & VL & $\begin{array}{c}T E R T, \text { c. } 2266 \mathrm{C}>\top \\
\text { p. R756C }\end{array}$ & $\begin{array}{l}\text { Oxymetholone, } \\
\text { danazol }\end{array}$ & N/A & N/A & N/A & 15 & $\begin{array}{l}\text { Cyanosis, } \\
\text { hypoxia, } \\
\text { clubbing }\end{array}$ & 16 & r & Y & $\mathrm{N}$ & 25 \\
\hline 2 & 27 & None & Moderate & $\mathrm{VL}^{*}$ & $\begin{array}{c}\text { RTEL1, } \\
\text { c.2227G>A } \\
\text { p.D734N } \\
+ \\
\text { c. } 2684 \mathrm{C}>\mathrm{T} \\
\text { p.P895L }\end{array}$ & Danazol & N/A & N/A & N/A & 32 & None & 52 & $\mathrm{~N}$ & Y & $\mathrm{N}$ & 32 \\
\hline 3 & 21 & None & Moderate & $\mathrm{VL}^{\#}$ & $\begin{array}{c}\text { TERT, c.994G>A } \\
\text { p. } 1062 \mathrm{~A}>\mathrm{T}+ \\
\text { c.844T>C } \\
\text { p. } 5795 \mathrm{P}\end{array}$ & Danazol & N/A & N/A & N/A & 27 & $\begin{array}{l}\text { No } \\
\text { symptoms, } \\
\text { clubbing }\end{array}$ & 53 & $\mathrm{~N}$ & Y & $\begin{array}{l}\text { Hepatic fibrosis, } \\
\text { splenomegaly, } \\
\text { portal HTN }\end{array}$ & 27 \\
\hline 4 NCl 291-1 & 18 & S, DN & Moderate & VL & $\begin{array}{c}\text { Compound het. PARN } \\
\text { c.19A }> \\
\text { p.N7H; gene deletion }\end{array}$ & HСT & $\begin{array}{c}\text { Severe } \\
\text { thrombocytopaenia" }\end{array}$ & 21 & Flu/alem, CSA/MMF & 21 & $\begin{array}{l}\text { Dyspnoea on } \\
\text { exertion, } \\
\text { clubbing }\end{array}$ & 28 & r & Y & $\mathrm{N}$ & 24 \\
\hline 5 NCl 216-1 & 8 & DN, L & Severe & VL & Unknown & HCT & Aplastic anaemia & 9 & $\begin{array}{l}\text { Flu/bu/CPM/ATG, } \\
\text { tacro/T-cell depletion }\end{array}$ & 14 & $\begin{array}{l}\text { Dyspnoea on } \\
\text { exertion }\end{array}$ & 50 & r & r & $\mathrm{N}$ & 17 \\
\hline $6 \mathrm{NCl} 440-1$ & 3.5 & S, DN & Severe & VL & $\begin{array}{c}D K C 1, \text { c. } 1223 C>T p . \\
\text { T4081 }\end{array}$ & $\begin{array}{l}\text { ATG/CSA, androgen, } \\
\text { G-CSF, darbepoetin, } \\
\text { HCT }\end{array}$ & Aplastic anaemia & 7 & $\begin{array}{c}\text { Flu/CPM/ATG, CSA/ } \\
\text { MMF }\end{array}$ & 12 & $\begin{array}{l}\text { Dyspnoea, } \\
\text { clubbing }\end{array}$ & 48 & $\mathrm{~N}$ & N/A & $\mathrm{N}$ & 14 \\
\hline 7 & 17 & S, DN, L & None & N/A & TINF2 & HCT & MDS & 5 & TBI, CSA/MTX & 13 & $\begin{array}{l}\text { Hypoxia, } \\
\text { dyspnoea on } \\
\text { exertion, } \\
\text { clubbing }\end{array}$ & 18 & $\mathrm{~N}$ & y & $\mathrm{N}$ & d.19 \\
\hline $8 \mathrm{NCl} 297-2$ & 16 & S, DN, L & Severe & $\mathrm{VL}$ & $\begin{array}{c}\text { RTELI, c.3361delG p. } \\
\text { A1121LfsXS6, c.1338+3 } \\
A>G \text { IVS15+3 A>G }\end{array}$ & HCT & Aplastic anaemia & 19 & $\begin{array}{l}\text { Flu/CPM/alem/TBI, } \\
\text { tacro/MMF }\end{array}$ & 22 & Dyspnoea & 56 & Y & Y & $\begin{array}{l}\text { Mild hepatic } \\
\text { fibrosis, portal } \\
\text { HTN }\end{array}$ & 22 \\
\hline 9 NCl 349-1 & 5.5 & $\mathrm{~S}, \mathrm{DN}, \mathrm{L}$ & Severe & VL & $\begin{array}{c}\text { TINF2, c. } 8456>A, p . \\
\text { R282H }\end{array}$ & HCT & Aplastic anaemia & 5.7 & $\begin{array}{l}\text { Flu/CPM/alem/TBI, } \\
\text { CSA/MMF }\end{array}$ & 12 & $\begin{array}{l}\text { Dyspnoea, } \\
\text { cough }\end{array}$ & N/A & r & N/A & N & d. 13 \\
\hline 10 & N/A & N/A & N/A & N/A & $\begin{array}{c}\text { TINF2, } \\
c .845 G>A, p . R 282 H\end{array}$ & HCT & Aplastic anaemia & 2.9 & $\begin{array}{l}\text { Flu/alem/CPM/anti } \\
\text { CD-45, CSA/MMF }\end{array}$ & 7 & Hypoxia & N/A & $\mathrm{N}$ & Y & $\mathrm{N}$ & 10 \\
\hline 11 & 4 & $\mathrm{~S}, \mathrm{DN}, \mathrm{L}$ & Moderate & VL & $\begin{array}{l}\text { TINF2, c.805C>T, p. } \\
\text { Q269XX }\end{array}$ & НСт & Aplastic anaemia & 4.7 & $\begin{array}{c}\text { Flu/alem/anti-CD45, } \\
\text { Tacro }\end{array}$ & 10 & $\begin{array}{l}\text { Progressive } \\
\text { dyspnoea }\end{array}$ & N/A & Y & Y & $\begin{array}{l}\text { Mild hepatic } \\
\text { fibrosis, } \\
\text { splenomegaly, } \\
\text { portal HTN }\end{array}$ & 11 \\
\hline $12 \mathrm{NCl} 145-1$ & 9 & S, DN & Severe & VL & $\begin{array}{c}\text { TINF2, c.844C>A } \\
\text { p.R282S }\end{array}$ & НСT & Aplastic anaemia & 10.8 & $\begin{array}{l}\text { Flu/bu/CPM/ATG, } \\
\text { Tacro/T-cell } \\
\text { depletion }\end{array}$ & 15 & $\begin{array}{c}\text { Dyspnoea on } \\
\text { exertion }\end{array}$ & 37 & $\mathrm{~N}$ & $\mathrm{~N}$ & $\begin{array}{l}\text { Hepatic fibrosis, } \\
\text { s/p } \\
\text { splenectomy }\end{array}$ & d. 16 \\
\hline $13 \mathrm{NCl} 438-1$ & 1 & DN & Severe & VL & $\begin{array}{c}\text { TINF2, } \\
\text { c. } 844 \mathrm{C}>\mathrm{A} \\
\text { p. } 2282 \mathrm{~S}\end{array}$ & НСT & Aplastic anaemia & 1.5 & $\begin{array}{l}\text { Flu/CPM/ATG, } \\
\text { CSA }\end{array}$ & 3 & $\begin{array}{l}\text { Chronic } \\
\text { hypoxia }\end{array}$ & N/A & $\mathrm{N}$ & Y & $\mathrm{N}$ & d. 4 \\
\hline
\end{tabular}

TBD: telomere biology disorder; HCT: haematopoietic stem cell transplantation; GVHD: graft versus host disease; DLCo: diffusing capacity of the lung for carbon monoxide; TTCE: transthoracic contrast echocardiogram; L: oral leukoplakia; VL: "very low" telomere length, <1st percentile for age in all leukocyte subsets measured using flow cytometry and fluorescence in situ hybridisation (unless indicated by ${ }^{\#}$; N/A: not available or not applicable; Y: yes; N: no; HTN: hypertension; S: skin pigmentation; DN: dysplastic nails; flu: fludarabine; alem; alemtuzumab; CSA: ciclosporin; MMF: mycophenolate mofetil; bu: busulfan; CPM: cyclophosphamide; ATG: antithymocyte globulin; tacro: tacrolimus; G-CSF: granulocyte colony-stimulating factor; MDS: myelodysplastic syndrome; TBI: total body irradiation; MTX: methotrexate; d.: died; s/p: status-post. \#: telomere length <1st percentile for age measured by quantitative PCR; ${ }^{~}$ : HCT for severe thrombocytopaenia that was precluding candidacy for lung transplant. 
after right heart) in 10 (91\%) out of 11 patients who underwent TTCE. Two patients who did not undergo TTCE had PAVMs confirmed by abnormal radioisotope lung perfusion scan and/or cardiac catheterisation. Five patients underwent lung perfusion scans that confirmed the presence of right-to-left shunting with tracer uptake in the brain and/or kidney, including the patient with a negative TTCE. Intrapulmonary shunt assessment of arterial blood gases at sea level in one patient showed decreased shunting from sitting upright (arterial oxygen tension $\left(\mathrm{PaO}_{2}\right) 32 \mathrm{mmHg}$ on room air and $102 \mathrm{mmHg}$ on $100 \%$ oxygen; $32.8 \%$ shunt $)$ to supine posture $\left(\mathrm{PaO}_{2} 247 \mathrm{mmHg}\right.$ on $100 \%$ oxygen; $21.8 \%$ shunt $)$, in concordance with his orthodeoxia and platypnoea. Only patient 5 had PAVMs visible on computed tomography scan and underwent coiling of the same. Her clinical course was complicated by development of a brain abscess 3 months after coiling, attributed to a bacterial embolus consequent to right-to-left shunting. The remaining patients had very small or microscopic PAVMs that were not amenable to transcatheter embolisation. Importantly, nine (69\%) out of 13 patients did not have laboratory or radiological evidence of liver disease at the time of PAVM diagnosis.

In summary, this case series establishes PAVMs as a clinically important pulmonary phenotype in DC/ TBD and one that may occur in the absence of overt HPS, in the absence of symptoms, and in patients of any age, genotype or phenotype (table 1). The mechanism underlying the development of vascular malformations in patients with aberrant telomere biology is not known. Vascular complications previously reported in DC/TBD have only recently been described as phenotypic features of the DC/TBD spectrum, such as in Revesz syndrome and Coats' plus [1,9]. Further research is needed to determine whether PAVMs are a consequence of telomere dysfunction; whether they are associated with transforming growth factor- $\beta$ signalling pathways similar to hereditary haemorrhagic telangiectasia (HHT) [12], an autosomal dominant disease of abnormal angiogenesis; and if any association exists between HCT and PAVMs in DC/TBD.

Timely and accurate diagnosis of PAVMs in DC/TBD is essential for appropriate clinical care and prevention of life-threatening complications (e.g. transient ischaemic attacks, stroke or brain abscesses) caused by paradoxical embolism in the setting of a right-to-left shunt. Multiple diagnostic modalities may be used for the detection of PAVMs including TTCE, DLCO, 6-min walk test and quantification of abnormal physiological shunting by arterial blood gases at sea level. Of these, TTCE is the most sensitive (close to $100 \%$ sensitivity reported in HHT) [13]. While pulmonary function tests are nonspecific, isolated decrease in DLCO may indicate abnormal shunting, warranting evaluation for occult PAVMs [14].

This case series reports nine patients with DC/TBD who developed PAVMs in the absence of overt HPS. However, it is not clear whether HPS and PAVMs occur along a continuum as components of one disorder or whether PAVMS can occur without concurrent or future development of liver disease [10]. With no known curative medical treatment options for PAVMs not amenable to transcatheter embolisation, clinicians need to be aware of the therapeutic challenges of PAVMs. Anecdotal reports of agents, including nifedipine and danazol among others have been inconsistent with respect to improvement of symptoms. Lung transplantation, which is an option for PAVMs not surgically treatable, would be unsuccessful if HPS was the underlying cause. In that instance, liver transplantation would be considered and is associated with significant mortality and morbidity [15].

In conclusion, PAVMs are a pulmonary phenotype of DC/TBD that may occur independently of HPS, in asymptomatic patients, across any phenotypic or genotypic presentation. The NCI's IBMFS study includes 145 affected DC patients, of whom seven (5\%) were symptomatic of and diagnosed with PAVMs and are included here [11]. We expect that the prevalence of PAVMs in DC/TBD will be higher with formal evaluation of PAVMs across all patients, since PAVMs can occur in the absence of symptoms. Isolated decrease in DLCO and/or hypoxia in DC patients warrant further investigations for PAVM, including TTCE, lung perfusion scan and evaluation of intrapulmonary shunting. Further research on the underlying biological mechanisms, including the pathophysiologic relationship between PAVMs and HPS and therapeutic options are needed to be able to better manage and treat these patients.

Payal P. Khincha ${ }^{1}$, Alison A. Bertuch ${ }^{2}$, Suneet Agarwal $^{3}$, Danielle M. Townsley ${ }^{4}$, Neal S. Young ${ }^{4}$, Siobán Keel ${ }^{5}$, Akiko Shimamura ${ }^{3}$, Farid Boulad ${ }^{6}$, Tregony Simoneau ${ }^{7}$, Henri Justino ${ }^{2}$, Christin Kuo ${ }^{8}$, Steven Artandi ${ }^{9}$, Charles McCaslin ${ }^{10}$, Des W. Cox ${ }^{11}$, Sara Chaffee ${ }^{12}$, Bridget F. Collins ${ }^{13}$, Neelam Giri ${ }^{1}$, Blanche P. Alter ${ }^{1}$, Ganesh Raghu ${ }^{13,14}$ and Sharon A. Savage ${ }^{1,14}$

${ }^{1}$ Clinical Genetics Branch, Division of Cancer Epidemiology and Genetics, National Cancer Institute, National Institutes of Health, Bethesda, MD, USA. ${ }^{2}$ Baylor College of Medicine, Houston, TX, USA. ${ }^{3}$ Division of Haematology/Oncology, Boston Children's Hospital, Boston, MA, USA. ${ }^{4}$ Hematology Branch, National Heart, Lung, and Blood Institute, NIH, Bethesda, MD, USA. ${ }^{5}$ Division of Haematology, Dept of Medicine, University of Washington, Seattle, WA, USA. ${ }^{6}$ Paediatric Oncology and Bone Marrow Transplant Service, Dept of Paediatrics, Memorial Sloan Kettering Cancer Centre, New York, NY, USA. ${ }^{7}$ Dept of Pulmonology, Connecticut Children's Medical Centre, Hartford, CT, USA. ${ }^{8}$ Dept of Pulmonology, Lucile Packard Children's Hospital Stanford, Palo Alto, CA, USA. ${ }^{9}$ Cancer Biology Program, Stanford University School of Medicine, Palo Alto, CA, USA. ${ }^{10}$ Helen DeVos Children's Hospital, Grand Rapids, MI, USA. 
${ }^{11}$ Paediatric Respiratory Medicine, Our Lady's Children's Hospital, Dublin, Ireland. ${ }^{12}$ Paediatric Haematology Oncology, Children's Hospital at Dartmouth, Dartmouth-Hitchcock Medical Centre, Lebanon, NH, USA. ${ }^{13}$ Centre for Interstitial Lung Diseases, Division of Pulmonary and Critical Care Medicine/Dept of Medicine, University of Washington, Seattle, WA, USA. ${ }^{14}$ Both authors contributed equally.

Correspondence: Payal P. Khincha, Division of Cancer Epidemiology and Genetics, National Cancer Institute, 9609 Medical Centre Drive, Room 6E562, MSC 9772, Bethesda, MD 20892, USA. E-mail: khinchapp@mail.nih.gov

Received: May 192016 | Accepted after revision: Sept 072016

Acknowledgements: This case series is the first completed research effort of the Clinical Care Consortium for Telomere Associated Ailments (CCCTAA), formed in 2013. We thank the patients, their families and the referring clinicians for their valuable contributions to this study.

Support statement: This work was supported by the intramural research programme of the National Cancer Institute (Rockville, MD, USA), National Institutes of Health (NIH; Bethesda, MD, USA), the National Heart, Lung and Blood Institute, NIH and the Translational Research Program at Boston Children's Hospital (Boston, MA, USA). Funding information for this article has been deposited with Open Funder Registry.

Conflict of interest: Disclosures can be found alongside this article at erj.ersjournals.com

\section{References}

1 Ballew BJ, Savage SA. Updates on the biology and management of dyskeratosis congenita and related telomere biology disorders. Expert Rev Hematol 2013; 6: 327-337.

2 Bertuch AA. The molecular genetics of the telomere biology disorders. RNA Biol 2016; 13: 696-706.

3 Alter BP, Baerlocher GM, Savage SA, et al. Very short telomere length by flow fluorescence in situ hybridization identifies patients with dyskeratosis congenita. Blood 2007; 110: 1439-1447.

4 Gordijn SJ, Brand PL. A boy with breathlessness, digital clubbing and central cyanosis. Eur J Pediatr 2004; 163 $129-130$.

$5 \quad$ Hirota T, Yamagami T, Nakamura T, et al. Small pulmonary arteriovenous fistulae revealed by scintigraphy during selective injection of ${ }^{99} \mathrm{Tc}^{\mathrm{m}}$-macroaggregated albumin. Br J Radiol 2004; 77: 445-448.

6 Sands A, Dalzell E, Craig B, et al. Multiple intrapulmonary arteriovenous fistulas in childhood. Pediatr Cardiol 2000; 21: 493-496.

7 Samuel BP, Duffner UA, Abdel-Mageed AS, et al. Pulmonary arteriovenous malformations in dyskeratosis congenita. Pediatr Dermatol 2015; 32: e165-e166.

8 Dokal I. Dyskeratosis congenita in all its forms. Br J Haematol 2000; 110: 768-779.

9 Gorgy AI, Jonassaint NL, Stanley SE, et al. Hepatopulmonary syndrome is a frequent cause of dyspnea in the short telomere disorders. Chest 2015; 148: 1019-1026.

10 Vettukattil JJ. Pathogenesis of pulmonary arteriovenous malformations: role of hepatopulmonary interactions. Heart 2002; 88: 561-563.

11 Alter BP, Giri N, Savage SA, et al. Malignancies and survival patterns in the National Cancer Institute inherited bone marrow failure syndromes cohort study. Br J Haematol 2010; 150: 179-188.

12 Chung MG. Hereditary hemorrhagic telangiactasia. In: Islam MP and Roach ES, eds. Handbook of Clinical Neurology. Amsterdam, Elsevier, 2015; pp. 185-197.

13 Faughnan ME, Palda VA, Garcia-Tsao G, et al. International guidelines for the diagnosis and management of hereditary haemorrhagic telangiectasia. J Med Genet 2011; 48: 73-87.

14 Gossage JR, Kanj G. Pulmonary arteriovenous malformations. A state of the art review. Am J Resp Crit Care Med 1998; 158: 643-661.

15 Swanson KL, Wiesner RH, Krowka MJ. Natural history of hepatopulmonary syndrome: impact of liver transplantation. Hepatology 2005; 41: 1122-1129. 